\title{
СОЦІАЛЬНА РЕАБІЛІТАЦІЯ
}

УдК 364.2

DOI: https://doi.org/10.17721/2616-7786.2018/4-1/9

Н. Гриб, магістр

Київський національний університет імені Тараса Шевченка, Київ, Україна

\section{ПРОФІЛАКТИКА ДЕСТРУКТИВНОЇ АГРЕСИВНОСТІ У ВІЙСЬКОВОСЛУЖБОВЦІВ}

\begin{abstract}
Присвячено актуальній на даний час темі, адже в умовах сучасної соціально-психологічної незахищеності в Україні відсутній комплексний підхід організації соціально-психологічної профрілактики наслідків психотравматичних загострень деструктивної агресивності військовослужбовців, які постраждали в умовах участі у бойових діях. Метою роботи є не лише теоретичний аналіз проблеми, а й практичне дослідження ситуації, що існує на даний момент. Це дає змогу зробити висновки та профілактичні рекомендації, які надалі можна впроваджувати в практичну діяльність не лише соціальних працівників, психологів, а й командирів.

Тому дослідження спрямоване на вивчення основних індивідуально-психологічних детермінант формування деструктивної агресивності та розробка на основі цього відповідних напрямів реабілітаційної роботи з їі попередження у військовослужбовців.

Ключові слова: військовослужбовець, бойові дії, агресія, психотравмуючий вплив, деструктивна агресивність, професійна виправдана аересивність.
\end{abstract}

Постановка проблеми. Трансформаційні процеси, які виникають на шляху демократичних перетворень супроводжуються агресивними проявами. Викликають їх соціально-політичні протиріччя, що сьогодні присутні в усіх сфрерах життєдіяльності суспільства та у військовій сорері, зокрема. У суспільстві змінюються ціннісні орієнтації, комунікативні структури, утверджується ідеологічний плюралізм. Всі ці зміни дуже складно і проблемно позначаються на системі людських відносин у Збройних Силах України. Дослідження показують підвищення деструктивної агресивності військовослужбовців, внаслідок певної дезадаптації під психотравмуючим впливом екстремальних умов ризиконебезпечної службово-бойової діяльності, а особливо, в умовах безпосередньої участі в активних бойових діях [1].

Відомо, що особистість формується у ході діяльності, тому прояв агресивності в середовищі військовослужбовців може сприяти не тільки професійній, а й особистісній деформації. Природно агресивна поведінка призводить до ескалації конфлікту та загострення конфліктної ситуації, що ускладнює міжособистісні стосунки, негативно впливає на морально-психологічний стан військовослужбовців у підрозділах та військових частинах.

Мета дослідження полягає у розкритті зв'язку агресивної поведінки із психологічними особливостями особистості та вивченні основних напрямів профрілактичної роботи з попередження деструктивної агресивної поведінки у військовослужбовців.

Аналіз досліджень та публікацій. Протягом століть питання агресії та агресивності турбувала кращі уми людства, її розглядали з різних позицій: фрілософських, релігійних, літературних тощо. Протягом довгого періоду часу погляди науковців змінювались і на сьогоднішній день, дана проблема стала предметом систематичних досліджень. В сучасній психологічній літературі відсутнє єдине визначення поняття "агресія". Дослідники, які займались проблемою агресії, виділяють ії̈ структуру (Р. Берон, Б. Басс, Е. Фромм), її сутнісні характеристики (Х. Хекхаузен, Р. Берон, Д. Річардсон), описують ії̈ прояви (А. Реан, Л.В. Зубова, В.А. Дереча, С.Н. Еніколопов). А. Адлер агресивну поведінку розглядає з позиції доступності спостереження за актами агресії, Л. Берковіц - з позиції цільової установки.

3 погляду соціальної психології агресію розуміють як особливу форму соціальної поведінки, яка формується соціальним світом індивіда і, відповідно, впливає на цей світ та його представників [2].
Якщо проаналізувати роботи 3. Фрейда, то можна простежити, що його теорія агресивності постійно змінювались і в своєму розвитку пройшла три етапи. На першому етапі було висунуто дві гіпотези: про агресивність в якості однієї із складових сексуального інстинкту, який спрямовується на збереження та відтворення життя. Другий етап свідчить про те, що всі агресивні дії виявляються біологічно виправданими, тому що стримування чи придушення агресивності може призвести до різного роду хвороб і психічних розладів. 3. Фрейд вважав, що агресивне поводження по своїй природі інстинктивне і неминуче [3].

Агресія виконує не лише руйнівну, а ще і адаптивну функцію, тобто, за визначенням Е. Фромма, є доброякісною, тому що сприяє підтримці життя i $€$ реакцією на загрозу вітальним потребам [4]. Якщо механізми контролю ослаблені, то людина схильна до прояву злоякісної агресії - жорстокості, яка не є біологічно адаптивною і не покликана захищати вітальні інтереси людини.

У свою чергу агресивність - це особистісна риса, що виражається в установочній схильності до агресивного реагування. Сутність агресивності виражається в готовності людини розпізнавати зовнішні стимули як потенційно небезпечні чи ворожі і вдаватися до агресивних форм реагування [5]. У цьому плані можна говорити про потенційно агресивне сприйняття і потенційно агресивну інтерпретацію як про стійкі особливості світосприйняття.

Підвищена агресивність $€$ однією з основних характеристик взаємодії військовослужбовців у Збройних Силах України. Психологи пов'язують це із низкою негативних факторів, які ускладнюють життєдіяльність, і як наслідок, є джерелом роздратувань та психічної напруги. Саме феномен бойових дій, екстремальний та ризиконебезпечний характер службової діяльності, жорстка статусна регламентація життєдіяльності є психотравмуючими чинниками, які загострюють деструктивну агресивність новобранців [6].

Англійський дослідник П. Дейл вважає, що в основі кожного прояву агресивної поведінки лежить емоційна агресія, депривація, відкидання [7]. Емоційну агресію можна кваліфікувати як ситуацію, коли військовослужбовець опиняється в групі, де всі курять, а він - ні. Його психічний статус при цьому визначається патерном залежності від імпульсивної поведінки товаришів по службі, що формується як наслідок спроб цього військовослужбовця зберегти власну ідентичність і самоповагу (патерн "залежності"). 
Агресія не виникає в "соціальному вакуумі". Навпаки, нерідко саме різні аспекти міжособистісної взаємодій призводять до її виникнення і зумовлюють ії фрорми i спрямованість [4]. Можливо саме тому так пильно увага приділяється фррустрації, тобто блокуванню розвертання цілеспрямованої поведінки. Хоча фрустрацію прийнято вважати однією 3 найпотужніших детермінантів агресії, дані про значність її впливу досить суперечливі.

Вербальна провокація теж здатна актуалізувати агресивні дії, словами користуються набагато частіше, ніж руками, ногами чи зброєю. У дослідженні Фельсона (1982-1984) можна знайти приклад того, яким чином погрози й образи переходять у фізичне насильство. Фельсон і Стедман (1983) резюмували результати своїх досліджень переростання словесної лайки в бійку й убивство такими словами: "Представляется, что именно месть не дает погаснуть и, более того, разжигает конфликты, в которых агрессивные действия обеих сторон и вероятность смертельного результата потерпевшей стороны сплетаются в единый узел"[8]. Дані Фельсона підкреслюють також найважливішу для цієї глави думку: агресія є процес взаємодії щонайменше двох людей. Як ми стверджували раніше, агресія виникає не в соціальному вакуумі, а у відповідь на реальні чи уявні дії та наміри інших людей.

Агресію не завжди породжують слова або вчинки інших людей. У багатьох випадках її викликають чи підсилюють фактори, не зв'язані тісно з постійно присутніми процесами соціальної взаємодії. 3 найбільш важливих зовнішніх детермінантів агресії одні $€$ елементами природного оточення, інші містять у собі ситуаційну інформацію, треті впливають на самоусвідомлення.

Існують додаткові джерела збудження, що підвищують рівень агресивності (ефект сумації). Ними можуть бути: короткочасна фрізична напруга, сексуально збуджуючі історії, фрільми, картинки, шуми, стимулюючі препарати. Тому основні фрактори, які сприяють агресивній поведінці військовослужбовців такі:

- соціально-економічні умови, в які потрапляє військовослужбовець;

- моральна атмосфера;

- умови мікросередовища (сім'я, родина, знайомі, рота, взвод);

- характер і система виховання, наявність значних стереотипів агресивних дій;

- вікові та індивідуально-психологічні особливості військовослужбовця (вони є основними факторами, який визначає своєрідність прояву агресії);

- психічні захворювання, травми, ослаблення здоров'я, фрізичні умови навколишнього середовища;

- вплив нікотину, алкоголю, наркотиків (призводить до вибухів агресії, що змінюється депресією).

Також потрібно зазначити, що важливим моментом в діагностиці агресивної поведінки особистості військовослужбовця $є$ визначення психологічного змісту ситуації, в якій спостерігається агресивна поведінка, і його внутрішнього змісту, який має для суб'єктавійськовослужбовця проявлена ним агресія.

Агресія військовослужбовців може відігравати як негативну, так і позитивну роль . По-перше, агресія може мати такі негативні впливи:

- створює підґрунтя, що підвищує конфоліктність військовослужбовців, нездатність до соціальної кооперації;

- зумовлює дезадаптацію військовослужбовців;

- у тривалих травмуючих ситуаціях може перешкоджати конструктивному виходу з них;

- забезпечує реалізацію мотиву бажання "завдати шкоди, поранення", здійснення умисного та цілеспрямованого заподіяння шкоди;
- сприяє реалізації потреби в певному емоційному вираженні;

- лежить в основі складних психічних захворювань;

- забезпечує здійснення помсти, самоствердження, примусу, впливу на іншого військовослужбовця, підвищення самооцінки.

По-друге, агресія може здійснювати такі позитивні впливи:

- забезпечення адаптації військовослужбовців, досягнення різноманітних зовнішніх вигод;

- здійснює певний регулюючий вплив, зосереджуючи процеси пізнання на предметному змісті, що має емоційне забарвлення;

- в критичній (фруструючій) ситуації може виконувати захисну функцію, функцію роз'яснення ситуації;

- здійснює оборонну функцію, захищаючи військовослужбовця від саморуйнування та від агресивних актів інших, захищаючи власні інтереси, я реакція на агресію;

- здійснює зняття емоційного напруження, відіграє роль деякої форми катарсису, знижуючи рівень спонукання до подальшої агресії;

- забезпечує компенсацію іншої агресії згідно з нормою відплати і помсти, в результаті чого соціальні відносини, виведені з рівноваги, приходить в норму;

- забезпечує вирішення конкретних завдань, соціально схвалюваних;

- здійснює експресивну функцію, забезпечуючи невербальну комунікацію;

- сприяє усуненню і знищенню перешкод, є необхідною в творчій діяльності;

- в обмеженому діапазоні створює підґрунтя для самостійності військовослужбовця, можливості зайняти активну життєву позицію.

Таким чином, агресія $є$ результатом засвоєння навичок агресивної поведінки і розвиток агресивної готовності військовослужбовців. Тому агресію варто розглядати як соціальну поведінку, яка включає навик і потребує научіння: щоб здійснити агресивну дію, військовослужбовець повинен багато знати: наприклад, які слова та дії спричиняють страждання, які "прийоми" виявляються "больовими" тощо. Ці знання військовослужбовець здобуває в процесі розвитку. Найкращим способом підкріплення агресивної поведінки є пряме схвалення [9].

Специфіка діяльності військовослужбовців полягає в тому, що вона пов'язана з ситуаціями, які мають непередбачувану розв'язку, пов'язана з підвищеною відповідальністю, необхідністю спілкуватись з різним контингентом громадян, витримувати психічні і фрізичні навантаження, потребує рішучих дій, здатності піти на ризик. При цьому агресивність, яка виникає у військовослужбовців у цих умовах, може проявлятись як у формі наполегливості, впертості (недеструктивна), так і у фоормі ворожості та ненависті (деструктивна), впливаючи на емоційний стан і поведінку особистості. Можна виділити такі основні джерела агресивності:

- Екстремальний характер ризиконебезпечних умов бойової діяльності яка пов'язана із насильством та насильницькими діями:

а) як протиправним насильством з боку супротивника чи правопорушника;

б) так і просоціальним правомірним насильством застосовуваним військовослужбовцем в інтересах суспільства і санкціонованого державою.

- Професійна деформація індивідуальних психологічних особливостей особистості військовослужбовця під впливом агресивного змісту бойової діяльності заснованої на регламентованому застосуванні насильства; 
- Сама специфіка служби передбачає прояв агресивності. Ненормований робочий день, побутова невлаштованість, часті переїзди на нове місце служби та відрядження, низька оплата праці та соціальна незахищеність, протидії з боку суспільства - фактори, які негативно позначаються на поведінці військовослужбовців;

- Особливості соціального оточення (найближче оточення). Тобто залежність військового від соціального оточення, в якому на першому місці стоїть його командир або начальник.

Аналіз конкретних фрорм агресивної поведінки, фактів нестатутних відносин, дисциплінарних проступків показує, що подібні за зовнішніми ознаками акти агресії, мають різну внутрішню природу. Якщо в одних випадках агресія викликана необхідністю захистити себе і носить переважно громадсько-випадковий, ситуаційний характер, то в інших - має місце стійка внутрішня детермінація агресії, яка безпосередньо обумовлена особистісними особливостями військовослужбовця. Це дає можливість визначити агресивність як вторинне, соціальне утворення індивіда, природну основу якого складають генетично первинні емоції, включені в процес соціалізації суб'єкта.

Призив новобранців у Збройні Сили, є для них новизною реальності, до якої ще не виробилась реакція пристосування. Зміна звичної та гарно знайомої діяльності - все це створює екстремальні умови життєдіяльності. Тому процес адаптації до військової служби потребує великих психологічних зусиль. Військовослужбовці мають адаптуватись до впливу специфічних факторів: до життя у великому колективі, до значних фізичних та нервових навантажень, до незвичних ризиконебезпечних і екстремальних умов службово-бойової діяльності та жорстко регламентованого статутами способу життя. Результат залежить, як від соціальнопсихологічних умов так і від психофізіологічної природи кожного солдата.

Профрілактика деструктивної агресивності військовослужбовців повинна представляти собою комплекс цілеспрямованих психологічно обґрунтованих і практично апробованих організаційних і морально-виховних заходів, які серед іншого включають оптимізацію міжособистісних стосунків військовослужбовців. Необхідна як індивідуальна корекція свідомості і поведінки кожного військовослужбовця, схильного до агресивних дій, так i нейтралізація негативних міжособистісних впливів, провокуючих агресивні прояви у військовослужбовців. Тільки комплексна профілактика, яка буде здійснюватися на рівні індивіда та його соціального оточення, може привести до пом'якшення агресивності.

Військовослужбовець повинен володіти певним рівнем професійно виправданої агресивності [10], достатнім для активних бойових дій. Якщо в суспільстві стоїть проблема зниження агресивності, то в армії навпаки, стоїть проблема активізації агресивної спрямованості та, в той же час, керованістю цією активністю.

Найбільш оптимальним методом психокорекції агресивності, який дозволяє досяпи хорошого результату, виступає раціональний психотерапевтичний тренінг. Даний метод не претендує на виявлення глибоких причин агресивності, але спрямований на усвідомлення та зміну агресивної поведінки військовослужбовців [11]. Такий підхід забезпечує отримання необхідних соціальних знань і навичок, особливо у сфері спілкування і спільному вирішенні виникаючих проблем чи поставлених задач.

При цьому в емоційній сфрері важливо, щоб у ході тренінгу військовослужбовець отримав емоційну підтримку, був знижений рівень тривоги, суб'єктивний рівень переживань, проведена корекція емоційного реагування.
У когнітивній сфері, яка виступає головною при корекції агресивної поведінки, важливе місце займає допомога особистості в усвідомленні істинних причин виникаючих проблем, підвищення ії самооцінки, узгодження внутрішнього образу, формування віри в свої сили, у можливості подолання ситуації, яка виникає.

У поведінковій сфрері у ході психотерапевтичного тренінгу можна корегувати неадекватні поведінкові реакції.

Висновок. Таким чином, основними соціальнопсихологічними задачами попереджувальної роботи 3 агресивністю військовослужбовців є:

1. На суб'єктивно-особистісному рівні:

- виявлення та корекція індивідуально-особистісних якостей військовослужбовця;

- підвищення нормативно-ціннісної представленості в свідомості військовослужбовців ідеалів і норм військової служби, міжособистісних стосунків;

- формування майбутньої перспективи діяльності, зміна внутрішніх диспозицій особистості військовослужбовця.

2. На організаційно-діяльному рівні:

- вплив на формування статусно-рольової структури групи;

- підтримка мікрогруп, діяльність яких підсилює позитивну тенденцію в розвитку військового колективу;

- підвищення ефективності діяльності по управлінню основними процесами у військовому колективі.

Прояв власної агресивності не всі здатні контролювати, відтак, спираючись на здобутки відомих психотерапевтів, ми можемо переконатись в тому, що контроль прояву емоцій і агресивності не може полягати в стримуванні, а лише в можливості виразу її в безпечних формах.

Список використаних джерел

1. Александров Д.О., Давидова О.В. та ін. Психологічне забезпечення оперативно-службової діяльності працівників міліції. Частина 8. Діагностика особистості працівника ОВС в системі психологічного супроводження : навч.-метод. посібн. - К.: НАВС, 2015 - 130 с.

2. Александров Д.О. Психологічна характеристика агресії та агресивності в структурі особистості працівників силових структур : матеріали III Всеармійської науково-практичної конференції "Актуальні проблеми становлення особистості професіонала в ризиконебезпечних професіях", 26 травня 2011 р. - Київ: Міністерство оборони України, Національний університет оборони України, 2011. - С. 16-19.

3. Бурлачук Л.Ф. Психодиагностика: Учебник для вузов. 2-е изд. СПб.: Питер, 2010. - 384 с.

4. Аргессия - одна из форм защиты "Я". Интервью Е. Клещенко с С.Н. Ениколоповым // Химия и жизнь. - 2006. - № 10. - С. 12-15

5. Егоров Р.С. Причинная структура расстройств приспособительных реакций у военнослужащих срочной службы // Сибирский вестник психиатрии и наркологи. - 2007. - № 1. - С. 222.

6. Караяни А.Г., Сыромятников И.В. Прикладная военная психология. СПб.: Питер, 2006. - 480 с.

7. Васильева О.С., Радишевская Я.Б. Влияние агрессивности курсантов на уровень их социально-психологической адаптации // Вопросы психологии. - 2005. - № 1. - С. 29-37.

8. Тохтамиш О.М. Посттравматичне зростання в реабілітаційному процесі // Вісник Київського національного університету імені Тараса Шевченка. Соціальна робота. - 2018. - № 1(3). С. 57-62.

9. Волянская Е.В. Основные этапы систематического изучения агрессии // Методологія, теорія та практика соціологічного аналізу сучасного суспільства : зб.наук.пр. - 2001. - С. 179-183.

10. Петрова А.Б. Психологическая коррекция и профилактика агрессивных форм поведения несовершеннолетних с девиантным поведением. М.: Флинта, МПСИ. -2008.

\section{References}

1. Alexandrov, D.O., Davydova, O.V. et al., 2015. Psychological support of operational and service activities of police officers. Part 8. Diagnosis of the personality of the officer in the system of psychological support. Teaching method. manuals $\mathrm{K} .:$ NAVS, $130 \mathrm{~s}$.

2. Alexandrov, D.O., (May 26, 2011). Psychological characteristic of aggression and aggressiveness in the structure of the personality of employees of the security forces. Materials of the Third All-Armenian Scientific and Practical Conference "Actual Problems of Professional Development in Risk-Safe Occupations" (p. 16-19). Kyiv: Ministry of Defense of Ukraine, National Defense University of Ukraine.

3. Burlachuk, LF, 2010. Psychodiagnostics: Textbook for high schools. 2nd ed. St. Petersburg: Peter, $384 \mathrm{pp}$.

4. Argeesia is one of the forms of protection "I". Interview with E.Kleschenko with SN Enikolopov (2006). Chemistry and Life, 10, 12-15. 
5. Egorov, RS, (2007). The causal structure of the disorder of adaptive reactions in the military service of emergency service, Siberian Journal of Psychiatry and narcology, 1, 222.

6. Karayani, AG \& Syromyatnikov, IV, 2006. Applied Military Psychology. St. Petersburg: Peter, 480s

7. Vasilieva, O.S. \& Radyshevskaya, Ya.B., (2005). Influence of aggression of cadets on the level of their social and psychological adaptation. Questions of psychology, 1, 29-37.

8. Tokhtamysh, OM, 2018. Post traumatic growth in the rehabilitation process. Bulletin of the Taras Shevchenko National University of Kyiv. Social work 1 (3), 57-62.

N. Hryb, Master student

Taras Shevchenko National University of Kyiv, Kyiv, Ukraine
9. Volyansky, E.V., 2001. The main stages of the systematic study of aggression. Methodology, theory and practice of sociological analysis of modern society: Zb.nauc.pr., 179-183.

10. Petrova, AB, 2008. Psychological correction and prevention of aggressive forms of behavior of minors with deviant behavior. $\mathrm{M}$.: Flint, MPSI

Надійшла до редколегії 01.11.18 Рецензовано 16.11.18

\section{PREVENTION OF MILITARY STAFF' DESTRUCTIVE AGGRESSIVENESS}

The work is devoted to the current theme, because in today's socio-psychological insecurity in Ukraine there is no comprehensive approach to the organization of socio-psychological prevention of the consequences of psychotraumatic exacerbations of destructive aggression of servicemen who suffered in the conditions of participation in hostilities. The aim of the work is not only a theoretical analysis of the problem, but also a practical study of the current situation. This allows us to make conclusions and preventive recommendations, which in the future can be introduced into the professional practice of not only social workers, psychologists, but also commanders and rehabilitants.

Therefore, the purpose of the study is to explore the main individual and psychological determinants of the formation of destructive aggressiveness and to develop on the basis of these appropriate directions of rehabilitation work to prevent it from servicemen. Empirical methods (observation, expert assessment of staff psychologists and commanders) were used for the study in order to identify soldiers who had destructive aggression after engaging in combat operations, interviewing, forming experiment, testing with psychodiagnostic techniques.The developed corrective program revealed a positive dynamics of personality changes that began to occur in the behavior of servicemen under the action of the measures taken. The training resulted in a significant decrease in physical aggression, a slight decrease in verbal aggression, a slight increase in indirect aggression. It is proved that the individual correction of consciousness and behavior of each serviceman inclined to aggressive actions, as well as the neutralization of negative interpersonal influences, provoking aggressive manifestations in the military. Such prevention can be carried out during a stressful situation, manifestation of aggression or after the end of an aggressive state. This program can be carried out during the service in part and after returning from the area of hostilities.

Keywords: serviceman, fighting, aggression, traumatic influence, destructive aggressiveness, professional readiness.

Н. Гриб, магистр

Киевский национальный университет имени Тараса Шевченко, Киев, Украина

\section{ПРОФИЛАКТИКА ДЕСТРУКТИВНОЙ АГРЕСИВНОСТИ У ВОЕННОСЛУЖАЩИХ}

Работа посвящена актуальной в настоящее время теме, ведь в условиях современной социально-психологической незащищенности в Украине отсутствует комплексный подход организации социально-психологической профилактики последствий психотравмирующей обостренной деструктивной агрессивности военнослужащих, пострадавших в условиях участия в боевых действиях. Целью работы является не только теоретический анализ проблемы, но и практическое исследование ситуации. Это позволяет сделать выводы и профилактические рекомендации, которые в дальнейшем можно внедрять в профессиональную практическую деятельность не только социальных работников, психологов, но и командиров.

Ключевые слова: военнослужащий, боевые действия, агрессия, психотравмирующие влияние, деструктивная агрессивность, профессионально оправдана агрессивность.

УдК 364.044.42

DOI: https://doi.org/10.17721/2616-7786.2018/4-1/10

О. Тохтамиш, канд. психол. наук, доц. Київський національний університет імені Тараса Шевченка, Київ, Україна ORCID iD 0000-0002-3850-535X

B. Пархоменко, магістр ГО Клуб "Еней" ORCID iD 0000-0003-4400-7397

A. Сарнацька, головний спеціаліст ГО Клуб "Еней", Київ, Україна ORCID iD 0000-0002-5253-291X

\section{ТЕХНОЛОГІЯ "WINGS" ЯК ЗАСІБ ПРОТИДIÏ НАСИЛЬСТВУ СТОСОВНО ЖІНОК ІЗ ГРУПИ ПІДВИЩЕНОГО РИЗИКУ}

Розглядаються фонкціональні складові комплексної профрілактичної та реабілітаційної технології "WINGS" (Women Initiating New Goals of Safety), розробленої групою соціальної інтервенції Колумбійського університету (США), з метою зниження ризику насильства щодо жінок з наркозалежністю. Аналізуються результати емпіричного дослідження ефективності ії застосування у ролі пілотного проекту в Україні. Пропонуються рекомендації щодо вдосконалення ії застосування з урахуванням отриманих результатів.

Ключові слова: профілактика насильства, жінки з наркозалежністю, короткотривале втручання, гендернозумовлене насильство, соціальний супровід.

Вступ. Розвиток соціальних послуг у демократичному суспільстві потребує аналізу ефективності та застосування передових інноваційних технологій, втілених також у діяльності соціальних служб інших країн [1; 2; 3]. Особливо це стосується соціального супроводу, профілактичних та інтервенційних засобів у соціальних службах, які працюють 3 сім'ями [4] та самотніми жінками з груп підвище- ного ризику, які належать до найменш захищених верств населення. Однією з актуальних проблем соціальної превенції $€$ насильство серед інтимних партнерів.

До групи підвищеного ризику щодо гендернозумовленого насильства відносяться, зокрема, жінки 3 наркозалежністю та жінки, які надають сексуальні послуги. Вони часто страждають від насильства, не завжди 